\title{
DUAL CAREER FOR STUDENTS WITH ATHLETE STATUS AT FACULTY OF ECONOMICS, UNIVERSITY OF LJUBLJANA
}

\author{
Vinko Zovko ${ }^{1}$ and Vedrana Sember ${ }^{2}$ \\ ${ }^{1}$ University of Ljubljana, School of economics and business, Ljubljana, Slovenia \\ ${ }^{2}$ University of Ljubljana, Faculty of Sports, Slovenia
}

UDK 796:371.214::378.633(497.12)

\begin{abstract}
SUMMARY
Elite athletes invest most of their time and energy in sports training and competitions, so they are often absent from the pedagogical process at university levels of education, which has an impact on the achievement of education. Too often, top-notch athletes are faced with difficulties in building out-of-sports careers, since many have no proper education and necessary experience. It is therefore important that they acquire an education at a time when competing in sport. At Faculty of economics, University of Ljubljana we've developed a system that facilitate education and help students with athlete status to achieve the desired vocational education, despite their intensive involvement in the top sport.
\end{abstract}

Keywords: elite athlete education, dual career, Faculty of economic, University of Ljubljana.

Corresponding author

Vinko Zovko

vinko.zovko@ef.uni-lj.si

\section{INTRODUCTION}

Dual career is a development of lifelong excellence of an individual athlete which is reflected through his goals in the sport performance, education and integration into the labor market. Dual career has been proven to be a good solution for balancing sport and other spheres of athletes' life and preparing them for the life after sport career (Stambulova, Engström, Franck, Linnér, \& Lindahl, 
2015), which also has been shown to be a factor in preventing athletic dropout and athletic identity foreclosure (Lavallee \& Robinson, 2007; Warriner \& Lavallee, 2008).

Supporting elite athletes in the field of education and sports career is very important if we want to avoid situations in which athletes are forced to decide between education and sport. Slovenia is offering support programs organized by the Slovenian Olympic Committee, which are, helping athletes to finish their education and become involved in the labor market.

\section{Dual career and students with athlete status}

Every nation is very proud of its professional athletes, who with their achievements become one of the most important ambassadors of their country. When their achievements reach peak in their career, most citizens support and encourage them. Bur when they finish with their sporting career, they often encounter many obstacles due to the various fields that are important, but were overseen. That mostly relates to the field of education (Aquilina, 2009).

Sport tends to take precedence, especially in sports where there are considerable rewards at an early age. The aim of the dual career plan is to encourage a dual success, not only in sport but also in academic studies, professional training and work. In 2013 the European Union (EU) published the EU Guidelines on Dual Careers of Athetes in order to highlight good practice and to improve the situation (European Commission, 2013). Slovenia followed European path with adopting five important documents regarding present subject: the National Sport Programme and the Implementation Plan of Sport (adopted in 2014), the Bridging Insurance Act of Professional and Top Athletes (adopted in 2015), The Sports Act and the Act on the Supplement to Pension for Work and Outstanding Achievements in the Field of Sport (adopted in 2017). Despite these efforts, many obstacles remain when it actually comes to implementing the dual career plan. Lack of time and motivation from those involved are often blamed for this. There is no unified system, that would involve legislative and executive level, universities and faculties on international or even national level.

\section{LITERATURE REVIEW AND BEST PRACTICES IN SELECTED EUROPEAN UNION COUNTRIES}

Many European countries have implemented different models for implementation dual career of elite sportsmen. Further, different European models will be presented. The review was prepared on the basis of the European 
Commission's official report on the dual career of top athletes (Amara, Aquilina, Henry, \& Taylor, 2004).

Table 1: European union countries dual career implementation models

\begin{tabular}{|c|c|}
\hline Country & Dual career model \\
\hline Belgium & $\begin{array}{l}\text { Belgium adopted law in } 1998 \text { to protect the rights of athletes } \\
\text { with three independent educational networks, the Belgian Olympic } \\
\text { Committee, the Inter-Federal Committee and the Sport and } \\
\text { Management to the authorities of the Flemish Community. }\end{array}$ \\
\hline Cyprus & $\begin{array}{l}\text { Cyprus has an incentive scheme for top athletes in the context of } \\
\text { its decisive sport development. Athletes are awarded with some kind } \\
\text { of "bonus points" if they want to continue their studies at the } \\
\text { University of Greece. The ability to allocate bonus points is limited to } \\
\text { a particular category in the scheme. }\end{array}$ \\
\hline Czech Republic & $\begin{array}{l}\text { There are no special adjustments in the Czech Republic elite } \\
\text { athletes regarding support for dual career. Nevertheless, students } \\
\text { athletes can still obtain some financial assistance granted by the } \\
\text { Czech Republic. }\end{array}$ \\
\hline Denmark & $\begin{array}{l}\text { Danish universities have special enrollment system for faculties. } \\
\text { At the Copenhagen Institute, they've decided that elite athletes would } \\
\text { be admitted to the faculty according to the quota achieved. Quota } 2 \text { is } \\
\text { a turning point and all those with a lower quota have to complete an } \\
\text { additional final examination. Students with athlete status can add } \\
\text { qualifications as elite athletes, which is considered as very important. }\end{array}$ \\
\hline Estonia & $\begin{array}{l}\text { In Estonia, only two universities offer special treatment to } \\
\text { athletes (universities in Tallinn and Tartu). Students are permitted to } \\
\text { complete the exams within the extended deadline. Support for } \\
\text { students is also available in the form of state awards and } \\
\text { scholarships. }\end{array}$ \\
\hline Finland & $\begin{array}{l}\text { Finland have launched individual programs in many universities } \\
\text { and polytechnics to meet the needs of athletes. At the university } \\
\text { level, there are two polytheists who run special programs for } \\
\text { obtaining a diploma. Support is also available in the form of grants, } \\
\text { scholarships and flexible studying programs. }\end{array}$ \\
\hline France & $\begin{array}{l}\text { In France, the provisions on higher education, admission and } \\
\text { adaptation of elite sportsmen have been accepted by ministry in } \\
\text { Circular No. } 1455 \text { in } 1987 \text {. This paper invites universities, school } \\
\text { principals and regional school directors to help combining sport and } \\
\text { study for elite sportsmen. }\end{array}$ \\
\hline
\end{tabular}


Germany

45 German universities have a cooperation agreement with the Olympic committee Support Centers, the German Sport Union and the National Sports Federations. The agreement allows them to adapt to students who want to perform a professional career of an athlete while studying at the faculty. These universities offer lower criteria for enrollment of athletes and strive to encourage athletes in their education.

Greece

Athletes who have achieved a remarkable sporting achievement do not need to complete the admission procedure for all study programs and can apply directly to:

- all university programs of their choice (without restrictions on the number of registered athletes),

- training schools for a police officer, a fire fighter officer, a naval officer (up to 10 admissions per year),

- one of the five science and sport departments (up to $30 \%$ of the total enrollment to these programs can be made by athletes without admission exams). It is important to note that the criteria have been significantly reduced for students with athlete status.

Hungary

Hungary has a system for easier entry to the university. In 2002, the Hungarian Olympic Committee (HOC) placed a new project called "Course of life program". As part of this project, the Hungarian Olympic Committee has concluded an agreement with 20 higher schools and universities. They offer an incentive scheme where the athlete can receive up to 5 bonus points, enabling easier enrollment at the faculty.

Ireland

Irish universities enables easier entry to the faculties. At the Waterford Institute of Technology, places are reserved for individuals who are competent for individual sports, but they do not have any financial help. At Dublin University elite sportsmen are advised to register for a degree in sport, sports organization and management. The Diploma in Sports Organizations and Management is a two-year, short-term program that aims to provide the foundation for athletes with the necessary skills to develop a career in sports.

Italy

Some Italian universities encourage athletes who study at institutes for sports science. Other athletes who study at universities are supported by university sports centers and they receive nonrefundable grants.

Latvia

Some universities have made it easier to enroll in college. Students achieving first 12 places at the Olympic, Paralympic Games, Youth and European Championships are exempted from the entrance 
exam. This also applies to secondary school students in Riga.

Lithuania

Elite athletes acquire certain bonus points for enrollment at the Lithuanian Academy of Sports Education, if they have achieved one of the first three places at major competitions.

\begin{tabular}{cl}
\hline Poland & $\begin{array}{l}\text { Athletes can enter faculty without Matura exam. The student- } \\
\text { athlete can also earn bonus points when enrolling at the faculty. This } \\
\text { applies to students who already have a qualification in the field of } \\
\text { sports education. } \\
\text { In Portugal they have a decreto in law, which stimulates top } \\
\text { athletes in enrolling at universities (this does not apply to military } \\
\text { and police institutions). Every year there is a different quota, } \\
\text { according to which the enrollment in faculties is measured. Since the } \\
\begin{array}{l}\text { 1992/93 academic year, Polish athletes at universities have a special } \\
\text { status that includes flexibility of schedules and flexibility in exams. }\end{array} \\
\text { There are no uniform rules in higher education that would } \\
\text { determine all the rights and duties of athletes' students. The } \\
\text { conditions for the exercise of rights are usually regulated separately } \\
\text { by individual higher education institutions, which vary widely in the } \\
\text { adaptation of the study of the student with athlete status. } \\
\text { In Spain, the) } 3 \% \text { of all free enrollment places at faculties are } \\
\text { reserved for elite athletes who meet academic / university } \\
\text { requirements. At the faculties of sports science and sports education, } \\
\text { 5\% of places are reserved for top athletes. Top sportsmen don't need } \\
\text { to pass the entrance exams and have certain advantages in } \\
\text { conducting the exams and with the study timetable. }\end{array}$ \\
\hline United & $\begin{array}{l}\text { The state helps athletes to combine sports and study by } \\
\text { coordinating schedules and exams based on their time available and } \\
\text { by distance learning and scholarships. }\end{array}$ \\
\hline
\end{tabular}

Since the School of Economics and Business at the University of Ljubljana (SEB LU) has just recently gained the certificate: ATHLETE FRIENDLY FACULTY, it seems appropriate to present this good practice, which could become model to other schools in the region. In the following chapter, we will present a concrete example that describes how Faculty of Business and Economics at the Faculty of Ljubljana (SEB LU) implemented program for top athletes. 


\section{EXAMPLE OF GOOD PRACTICE: SLOVENIA - FACULTY OF ECONOMICS AND BUSINESS, UNIVERSITY OF LJUBLJANA}

In Slovenia, some research has been made regarding dual career of elite athletes. Zevnik (2003) conducted a study on 40 elite Slovenian skiers and runners and found out that $60 \%$ of the respondents completed secondary school ( $71 \%$ were still middle school students) and that more than $50 \%$ of elite athletes continue with schooling. He emphasized, that the majority of respondents were still secondary school students and most of them were not financially dependable of sport results. Cecič Erpič (2002) found out that most of Slovenian athletes have a high school diploma (65\%), 28\% left their school because of their sports career, $5 \%$ did not decide to pursue their education career due to persuasion of the sporting career. Bon (2011) did a research on a sample of 56 handball male and female players of the sports - handball class of the Ljubljana Šiška high school. The results suggested, that students in the first year of secondary school want to play a professional handball, whilst the students of the older years give more emphasis to social life and entertainment. Lupo and colleagues (2015) in comparative study between Italian and Slovenia elite athletes found out, that Slovenian students are highly motivated for dual career.

Faculty of economics and business, University of Ljubljana (SEB LU) is also the only faculty in the wider region that has become the part of the elite group of triple accredited international schools (international accreditation of excellence EQUIS, AACSB and AMBA). This accreditation places the faculty among $1 \%$ of the world's best business and economics schools. Its greatness the SEB LU is also showing with dual career implementation and they were asked to present their sstem at the national convention in Ljubljana this year.

Decision and policy makers at SEB LU are aware of the needs and requirements of students with athlete status. That's why they've made a sport class at the faculty, which includes all students with athlete status in the current academic year. The status of an athlete is given to students who have written documents, which are proving the status of an elite athlete in accordance with the regulation in country (awarded prize on national level or recognized at university level). Each sports class has his own coordinator, normally a professor from the Faculty of Economics. The sports class is not the class of students enrolled into the same study year, but is a virtual class, that brings together all students with athlete status into one group, which is coordinated by full time professor. His role is related primarily to the planning and coordination of a dual career with students, since their other rights and benefits are regulated at the institutional level. SEB LU therefore provide students with assistance in the organization of their studies and it helps them to plan their obligations according to the schedule of sports obligations.

The most important adjustments for students with athlete status are: 
- students are not obliged to attend the whole pedagogical process, but they must fulfill all other obligations in the curriculum, which are a prerequisite for the entrance to the exam;

- time adjustment for grade assessment;

- additional assessment exams;

- adjustment and reduction of the exam scope;

- inclusion into tutoring system, which is carried out at the faculty. There are two types of tutoring: introductory and subject tutoring;

- individual assistance from professors - Skype contact hours, high response through e-mail;

- use of faculty facilities (gyms, fitness...);

- faculty offers diet food in cantinas;

- extension of student status;

- informations about the possibilities of dual career - job offering.

\section{CONCLUSION}

International Olympic Committee (IOC) and many national governments and sports authorities are becoming more aware of the problems related to the athlete's development in terms of regulating the compatibility of education and sporting activities. Despite some efforts, many obstacles remain when it actually comes to implementing the dual career plan and there is still a lot of room for improvement.

This article presents a review of good practices that have been implemented in 20 European countries. To develop optimal solution for dual careers on international level, more systematic engagement of various stakeholders (athletes, coaches, national administrative bodies in sports, academies, universities, governments and, ultimately, also some supranational bodies like European Union), will be required.

In short term it's difficult to expect that Europe will unify its rules related to dual careers. It makes more sense to start with implementation of the change in some regions, that have similar culture and common history. Here we see the opportunity for the Balkans to unite and to draw up uniform rules that would apply for students with athlete status in the region. By doing so, Balkan would send a clear message to other countries and maybe even the World. 


\title{
5. LITERATURE
}

1. Amara, M., Aquilina, D., Henry, I., \& Taylor, M. (2004). Education of young sportspersons (lot 1). Report Finale. Brussels.

2. Aquilina, D. A. (2009). Degrees of success: negotiating dual career paths in elite sport and university education in Finland, France and the UK. (C) D. Aquilina.

3. Bon, M. (2011). A sports career and education: characteristics of participants in specialised handball classes. Kinesiologia Slovenica, 17(1).

4. Cecić Erpič, S. (2002). Konec športne kariere: razvojno psihološki in športno psihološki vidiki. Fakulteta Za Šport, Ljubljana.

5. Lavallee, D., \& Robinson, H. K. (2007). In pursuit of an identity: A qualitative exploration of retirement from women's artistic gymnastics. Psychology of Sport and Exercise, 8(1), 119-141.

6. Lupo, C., Guidotti, F., Goncalves, C. E., Moreira, L., Doupona Topic, M., Bellardini, H., ... Capranica, L. (2015). Motivation towards dual career of European studentathletes. European Journal of Sport Science, 15(2), 151-160.

7. Stambulova, N. B., Engström, C., Franck, A., Linnér, L., \& Lindahl, K. (2015). Searching for an optimal balance: Dual career experiences of Swedish adolescent athletes. Psychology of Sport and Exercise, 21, 4-14.

8. Warriner, K., \& Lavallee, D. (2008). The retirement experiences of elite female gymnasts: Self identity and the physical self. Journal of Applied Sport Psychology, 20(3), 301-317.

\section{ДУАЛНА КАРИЈЕРА ЗА СТУДЕНТЕ СА СТАТУСОМ СПОРТИСТЕ НА ЕКОНОМСКОМ ФАКУЛТЕТУ УНИВЕРЗИТЕТА У ЉУБЉАНИ}

\begin{abstract}
САЖЕТАК
Елитни спортисти улажу већину свог времена и енергије у спортски тренинг и такмичења, тако да често изостају из педагошког процеса на универзитетским нивоима образовања, што има утицаја на успешност њиховог образовања. Пречесто, врхунски спортисти се суочавају са потешкоћама у изградњи спортске каријере, јер многи немају одговарајуће образовање и потребно искуство. Зато је важно да они стекну образовање у време када се такмиче у спорту. На Економском факултету Универзитета у Љубљани развили смо систем који олакшава образовање и помаже студентима са статусом спортисте да постигну жељено стручно образовање, упркос интезивном бављењу врхунским спортом.
\end{abstract}

Кључне речи: образовање елитних спортиста, дуална каријера, Економски факултет Универзитета у Љубљани 


\title{
ДУАЛЬНАЯ КАРЬЕРА ДЛЯ СТУДЕНТОВ СО СТАТУСОМ СПОРТСМЕНА НА ЭКОНОМИЧЕСКОМ ФАКУЛЬТЕТЕ ЛЮБЛЯНСКОГО УНИВЕРСИТЕТА
}

\begin{abstract}
АННОТАЦИЯ
Элитные спортсмены посвящают большую часть своего времени и тратят энергию на спортивные тренировки и соревнования, поэтому они часто пропускают мероприятия педагогического процесса вузовского уровня образования, что сказывается на шансах получить качественное образование. Слишком часто первоклассные спортсмены сталкиваются с трудностями, связанными с построением внепрофессиональной карьеры, поскольку многие из них не имеют ни надлежащей квалификации, ни опыта. Поэтому важно, чтобы они получали образование в тот период времени, когда состязаются в спортивных соревнованиях. На экономическом факультете Люблянского университета мы разработали систему, которая облегчает обучение и помогает студентам со статусом спортсмена достичь желаемого профессионального образования, несмотря на их интенсивное участие в ведущих видах спорта.
\end{abstract}

Ключевые слова: элитное спортивное образование, дуальная карьера, экономический факультет, Люблянский университет. 